\title{
Hydration of the lithospheric mantle in the northern Slave craton (Canada): constraints from combined FTIR and EBSD measurements on peridotite xenoliths
}

\author{
Qin Wang1*, Haojie Yan', Maya G. Kopylova ${ }^{2}$ \\ ${ }^{1}$ Nanjing University, Nanjing, China, qwang@nju.edu.cn,438463628@qq.com \\ ${ }^{2}$ University of British Columbia, Vancouver, Canada, mkopylov@eoas.ubc.ca
}

\section{Introduction}

Water contents of nominally anhydrous mantle minerals have significant influence on the mantle strength and change with magmatism and metasomatism. Measurements of water content in olivine from the cratonic mantle are therefore an important tool for deciphering deep mantle processes, both rheological and geochemical. Due to the fast eruption rate of kimberlites, peridotite xenoliths from kimberlites are the best samples to study the distribution of in-situ water contents in the cratonic lithospheric mantle.

Using a new method that combines Fourier transform infrared spectroscopy (FTIR) and electron backscatter diffraction (EBSD) analysis, we measured water contents and crystal preferred orientation (CPO) of olivine in peridotite xenoliths from the middle Jurassic Muskox kimberlite pipe (northern Slave craton, Canada). The results reveal contrasting water contents and fabrics of olivine in spinel peridotites and garnet peridotites, which highlight the importance of magmatism and metasomatism on deformation mechanisms of the mantle.

\section{Methods}

Infrared spectroscopy determines concentrations of $\mathrm{OH}$-groups in olivine based on the infrared light absorption coefficients, which differ depending on crystallographic directions in anisotropic minerals. Ideally, water contents in olivine should be analyzed on oriented grains using polarized infrared light. However, this method requires mineral separation and orientation. Based on results of Bell et al. (2003), an ellipsoid of water absorption coefficient (W) is established using W values along crystallographic directions [100], [010] and [001] (Figure 1a). Then based on the EBSD-derived orientation of an olivine grain, the specific water absorption coefficient along a certain direction (Ws) in the ellipsoid is determined. Finally, water content of the olivine grain is calculated using the Beer-Lambert equation.

Orientations of olivine and orthopyroxene were measured by the manually EBSD indexing using JEOL JSM-6490 electron microprobe equipped with an HKL Nordlys-S EBSD detector. The EBSD measurements were carried out at accelerating voltage of $20 \mathrm{kV}$, a working distance of 15-30 mm with $70^{\circ}$ tilt angle of a thin section (Figure $1 \mathrm{~b}$ ). Although it is difficult to determine the lineation and foliation of peridotite xenoliths, orthopyroxene generally develops the CPO with concentration of [001] axes parallel to the lineation and that of [100] axes normal to the foliation (Wang et al., 2013). Therefore we rotated the EBSD data to obtain the CPO of orthopyroxene, and then ploted pole figures of olivine.

Water contents of olivine were measured by the Bruker Vertex 70V FTIR spectrometry using polarized light. All thin sections were analyzed with the polarization direction of infrared light parallel to the long axis of the thin section ( $0^{\circ} / / \mathrm{X} 1$ direction). In addition, 3 garnet peridotite samples also have the FTIR analysis with the polarization direction of infrared light $90^{\circ}$ to the long axis of thin section $\left(90^{\circ} / / \mathrm{Y} 1\right.$ direction) (Figure 1c). For coarse olivine grains, there is no difference in water contents of olivine from core to rim. The results demonstrate reliability of this new method and homogenous water distribution in olivine in microscale (Table 1). All experiments were carried out at the State Key Laboratory for Mineral Deposits Research, Nanjing University. 
(a)

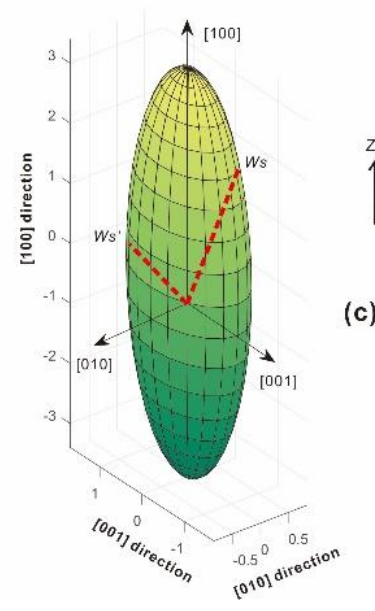

(b)

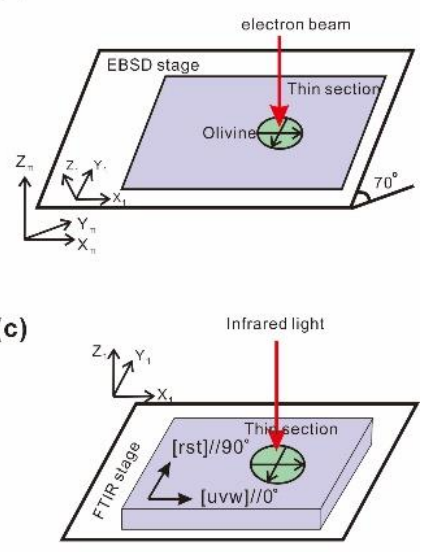

Figure 1: (a) Ellipsoid of water absorption coefficient of olivine, and coordinate systems in (b) EBSD and (c) FTIR experiments.

\section{Analytical Results}

Olivine infrared spectra (Figure 2) are similar to previouly published spectra for olivine (Bell et al., 2003). The dominance absorption in different polarization directions is between 3650 and $3450 \mathrm{~cm}^{-1}$, with absorption peaks at $3572 \mathrm{~cm}^{-1}$ and $3525 \mathrm{~cm}^{-1}$. To avoid effects of serpentinization, spectra with absorption peaks at $3650-3790 \mathrm{~cm}^{-1}$ were not included.

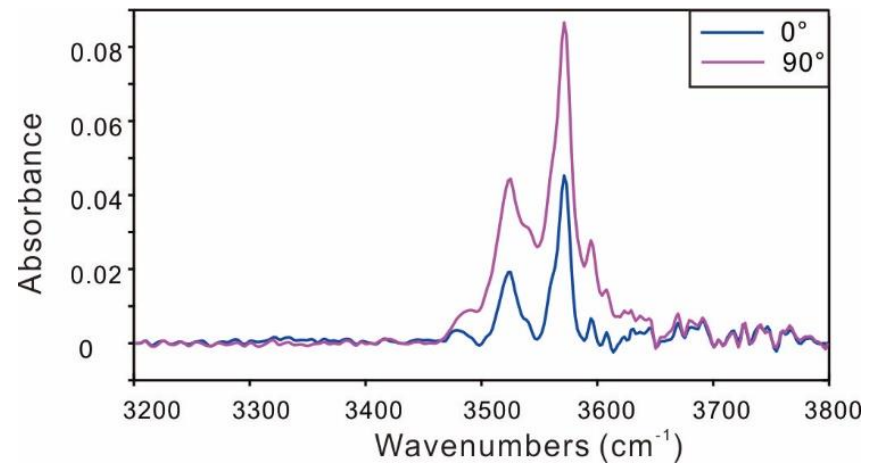

Figure 2: Polarized infrared spectra of olivine grains with polarization direction of $0^{\circ}$ and $90^{\circ}$.

Four garnet peridotites show porphyroclastic sheared texture and contain phlogopite, whereas three spinel peridotites have granoblastic coarse texture and one sample MOX7-62-3 contains hornblende. Olivine from 4 garnet peridotite samples has the average $\mathrm{Mg \#}$ of 90.5 and average water content of $82 \pm 5 \mathrm{ppm}$, and develops the B-type fabric due to dominance of the [001](010) slip system. In contrast, olivine from spinel peridotites shows the average $\mathrm{Mg} \#$ of 92 and average water content of $33 \pm 6 \mathrm{ppm}$, and the E-type fabric due to dominant activation of [100](001) slip system (Table 1 and Figure 3).

Our results suggest higher water concentration in the deeper part $(>100 \mathrm{~km})$ of the northern Slave craton. Wang (2010) summarized that the average water contents in olivine from cratonic kimberlite nodules is $17 \pm 13 \mathrm{ppm} \mathrm{H}_{2} \mathrm{O}$ for the unpolarized light and the Paterson's calibration, i.e., $\sim 60 \mathrm{ppm}_{2} \mathrm{O}$ for the polarized light using the Bell et al. (2003) calibration. Therefore, olivine in coarse-grained spinel peridotites from the Muskox kimberlite pipe kept very dry after the initial large degree of partial melting, whereas olivine in the sheared garnet peridotites has been hydrated above the average cratonic mantle. The calculated equilibrium P-T conditions for garnet peridotites are $1210 \pm 20^{\circ} \mathrm{C}$ and $6.0 \pm 0.3 \mathrm{GPa}$. This indicates hydrogen-enhanced strain localization in garnet peridotites near the lithosphereasthenosphere boundary (LAB), which is contrary to water-poor olivine from the LAB beneath the 
Kaapvaal craton (Preslier et al., 2010). Hydration of the lithospheric mantle beneath the deep northern Slave craton may record mantle metasomatism after formation of the cratonic root, which resulted in a weakened LAB and pre-condition of the Jurassic mantle to the formation of kimberlite melts.

\begin{tabular}{|c|c|c|c|c|c|c|c|c|}
\hline Sample No. & Lithology & $\begin{array}{c}\text { Grain } \\
\text { number }(\mathrm{N})\end{array}$ & $\begin{array}{l}\text { Water content } \\
\text { in section a }\end{array}$ & Water conten & at in section b & $\begin{array}{l}\text { Average water } \\
\text { content }\end{array}$ & $\mathrm{Mg} \#$ & Olivine fabric \\
\hline \multicolumn{3}{|c|}{ Polarization direction of infrared light } & $0 \% / \mathrm{X}_{1}$ & $0 \% / \mathrm{X}_{1}$ & $90^{\circ} / / \mathrm{Y}_{1}$ & & & \\
\hline MOX1-45-5 & Garnet peridotite & 86 & $89 \pm 17(\mathrm{~N}=44)$ & $93 \pm 17(\mathrm{~N}=21)$ & $92 \pm 18(\mathrm{~N}=21)$ & $91 \pm 17$ & 90.11 & {$[001](010)$} \\
\hline MOX25-124-8 & Garnet peridotite & 117 & $81 \pm 11(\mathrm{~N}=45)$ & $81 \pm 17(\mathrm{~N}=36)$ & $81 \pm 16(\mathrm{~N}=36)$ & $81 \pm 14$ & 90.58 & {$[001](010)$} \\
\hline MOX28-320-1 & Garnet peridotite & 82 & $83 \pm 11(\mathrm{~N}=34)$ & $75 \pm 12(\mathrm{~N}=24)$ & $76 \pm 10(\mathrm{~N}=24)$ & $76 \pm 12$ & 89.28 & {$[001](010)$} \\
\hline $\begin{array}{l}\text { MOX24-125- } \\
\text { OA }\end{array}$ & Garnet peridotite & 38 & $76 \pm 17$ & & & & 91.85 & {$[001](010)$} \\
\hline MOX3-78-8A & Spinel peridotite & 34 & $25 \pm 9$ & & & & 93.4 & {$[100](001)$} \\
\hline MOX7-62-3 & Spinel peridotite & 49 & $40 \pm 14$ & & & & 91.82 & {$[100](001)$} \\
\hline MOX7-97-6 & Spinel peridotite & 26 & $34 \pm 8$ & & & & 90.68 & {$[100](001)$} \\
\hline
\end{tabular}

Table 1: Water contents in ppm $\mathrm{H}_{2} \mathrm{O}, \mathrm{Mg} \#$ and fabric of olivine from the Muskox peridotite xenoliths
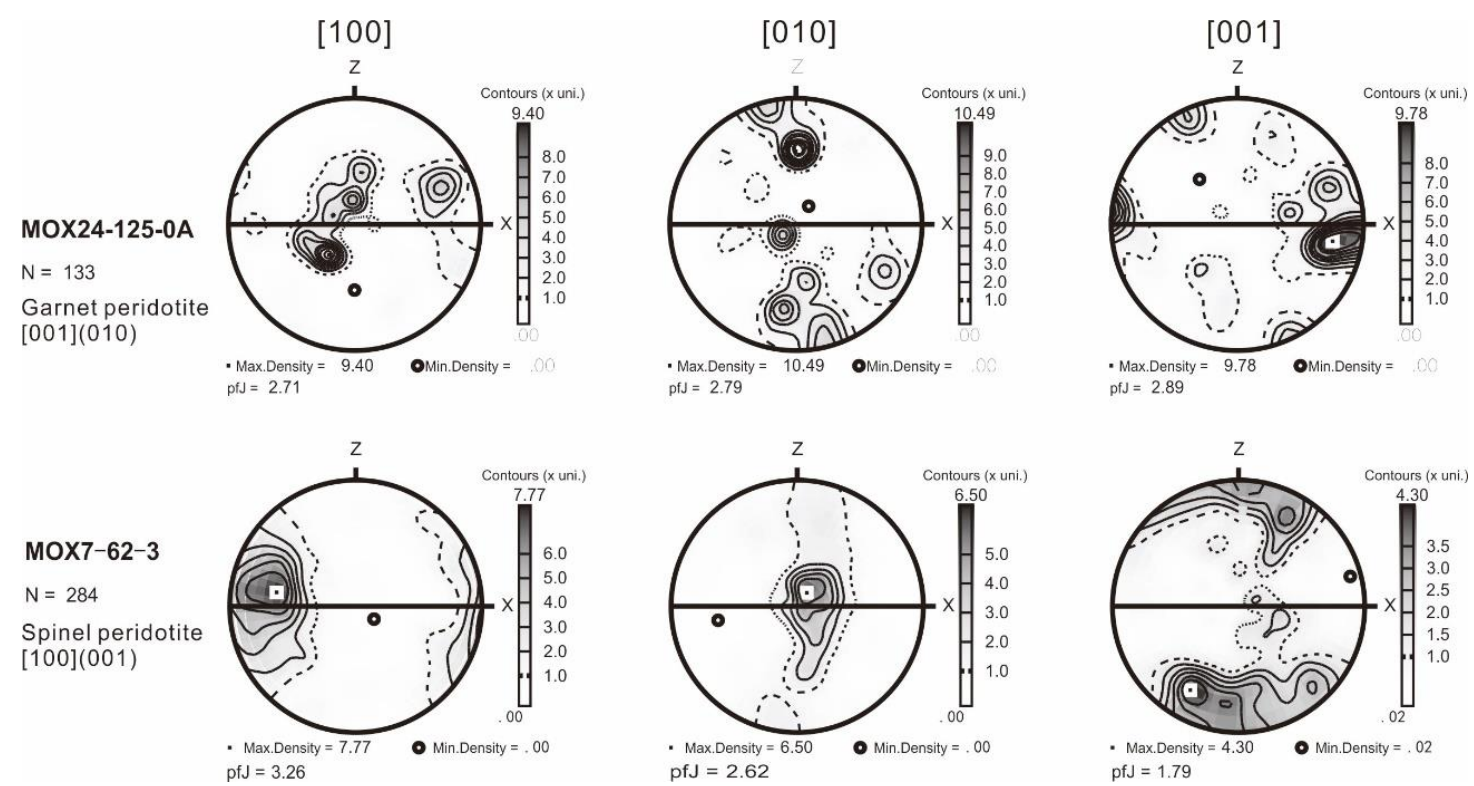

Figure 3: Lower hemisphere projection for pole figures of olivine from typical peridotite xenoliths. $X$ is parallel to the lineation, $\mathrm{Z}$ is normal to foliation, $\mathrm{N}$ is measured grain number.

\section{References}

Bell DR, Rossman GR, Maldener J, Endosch D, Rauch, F (2003) Hydroxide in olivine: a quantitative determination of the absolute amount and calibration of the IR spectrum. J Geophys Res 108: 2105. doi:10.1029/2001JB000679

Paterson MS (1982) The determination of hydroxyl by infrared absorption in quartz, silicate glasses and similar materials. Bull Mineral 105: 20-29

Peslier AH, Woodland AB, Bell DR, Lazarov M (2010) Olivine water contents in the continental lithosphere and the longevity of cratons. Nature 467: 78-82

Wang Q (2010) A review of water contents and ductile deformation mechanisms of olivine: implications for the lithosphere-asthenosphere boundary of continents. Lithos, 120: 30-41

Wang Q, Xia QK, O'Reilly SY, et al (2013) Pressure- and stress-induced fabric transition in olivine from peridotites in the Western Gneiss Region (Norway): implications for mantle seismic anisotropy. J Metamorph Geol 31: 91-111 